\title{
P369: Financial benefits after the implementation of antimicrobial copper in intensive care units (ICUs)
}

\author{
P Efstathiou ${ }^{1 *}$, E Kouskouni ${ }^{2}$, S Papanikolaou ${ }^{3}$, K Karageorgou $^{1}$, Z Manolidou $^{1}$, M Tseroni $^{1}$, E Logothetis $^{1}$, \\ C Petropoulou ${ }^{4}$, Karyoti $^{1}$
}

From 2nd International Conference on Prevention and Infection Control (ICPIC 2013)

Geneva, Switzerland. 25-28 June 2013

\section{Objectives}

Aim of this study was to evaluate the reduction on Intensive Care Unit (ICU) microbial flora after the antimicrobial copper alloy $\left(\mathrm{Cu}^{+}\right)$implementation as well as the effect on financial - epidemiological operation parameters.

\section{Methods}

Medical, epidemiological and financial data into two time periods, before and after the implementation of copper ( $\mathrm{Cu} 63 \%$ - Zn 37\%, Low Lead) were recorded and analyzed in a General ICU. The evaluated parameters were: the importance of patients' admission (Acute Physiology and Chronic Health Evaluation - APACHE II and Simplified Acute Physiology Score - SAPS), microbial flora's record in the ICU before and after the implementation of $\mathrm{Cu}^{+}$as well as the impact on epidemiological and ICU's operation financial parameters.

\section{Results}

During December 2010 and March 2011 and respectively during December 2011 and March 2012 comparative results showed statistically significant reduction on the microbial flora (CFU / $\mathrm{ml}$ ) by $95 \%$ and the use of antimicrobial medicine (per day per patient) by $30 \%(\mathrm{p}=0,014$ ) as well as patients hospitalization time and cost.

\section{Conclusion}

The innovative implementation of antimicrobial copper in ICUs contributed to their microbial flora significant reduction and antimicrobial drugs use reduction with the

National Health Operations Centre, Athens, Greece

Full list of author information is available at the end of the article apparent positive effect (decrease) in both patients hospitalization time and cost. Under the present circumstances of economic crisis, survey results are of highest importance and value.

\section{Disclosure of interest}

None declared.

\section{Author details}

${ }^{1}$ National Health Operations Centre, Athens, Greece. ${ }^{2}$ Medical School of the University of Athens, Microbiology laboratory of Aretaieio Hospital, Ministry of Health, Athens, Greece. ${ }^{3} \mathrm{ICU}$, Peiraikon General Hospital, Athens, Greece. ${ }^{4 " A g i a}$ Sofia" Childrens Hospital (NICU), Ministry of Health, Athens, Greece.

Published: 20 June 2013

doi:10.1186/2047-2994-2-S1-P369

Cite this article as: Efstathiou et al:: P369: Financial benefits after the implementation of antimicrobial copper in intensive care units (ICUs). Antimicrobial Resistance and Infection Control 2013 2(Suppl 1):P369.

Submit your next manuscript to BioMed Central and take full advantage of:

- Convenient online submission

- Thorough peer review

- No space constraints or color figure charges

- Immediate publication on acceptance

- Inclusion in PubMed, CAS, Scopus and Google Scholar

- Research which is freely available for redistribution

Submit your manuscript at www.biomedcentral.com/submit

\section{Ciomed Central}

( 2013 Efstathiou et al; licensee BioMed Central Ltd. This is an Open Access article distributed under the terms of the Creative Commons Attribution License (http://creativecommons.org/licenses/by/2.0), which permits unrestricted use, distribution, and reproduction in any medium, provided the original work is properly cited. 